\title{
How to Survive in Book Store Industry through Strengthening Brand Equity
}

\author{
Evita Sukmawati ${ }^{1 *}$, Leonnard Ong ${ }^{2}$ \\ ${ }^{1,2}$ Sekolah Tinggi Manajemen Ipmi, Jakarta, Indonesia 12750
}

\begin{abstract}
A B S T RA C T
This study aims to determine the influence of corporate positioning on brand equity. Data were obtained from the result of filling out questionnaires by 200 respondents who were all consumers of Gramedia Book Stores. The data were analyzed descriptively and quantitatively through Structural Equation Modelling (SEM) analysis. The findings revealed that the corporate positioning of the Gramedia Book Stores has a positive and significant effect on consumer brand equity. Further managerial implications are provided.
\end{abstract}

ARTICLE INFO

Keywords:

Corporate Identity,

Brand Image,

Structural Equation Modeling

\section{INTRODUCTION}

Over the years, there have been several approaches to conceptualize brand equity, being identified with the value added to the product due to the existence of a brand (Yoo, Donthu, \& Lee, 2000). A brand is defined as a valuable intangible asset, difficult to imitate (Roberts \& Dowling, 2002), that can offer a value proposition based on existing associations and transmit culture and values of the organization (Aaker, 2012), as well as help to achieve superior financial results (Roberts \& Dowling, 2002). Brand equity contributes greatly to attitudes accumulated in consumer minds (Ambler \& Styles, 1995), preferences (Park \& Srinivasan, 1994), perceptions (Lassar, Mittal, \& Sharma, 1995; Yoo, Donthu, \& Lee, 2000), and consumers' behavior (Aaker, 2012). In this sense, one of the most salient contributions in the brand equity literature is Aaker's conceptualization. Aaker (2012) defined brand equity as a set of assets and liabilities linked to a brand name and symbol that adds to (or subtracts from) the value provided by a product or service to a firm and its customers. Considering both perceptual and market behavior measures, Aaker (2012) suggested dimensions of brand loyalty, perceived quality, association, differentiation, awareness, and market behavior as sources of brand equity. Previous studies have discussed determinants of brand equity, including Iglesias, Markovic, \& Rialp (2019), Guitart, Gonzalez, \& Stremersch (2018), Biedenbach, Kao \& Lin (2016), Sasmita \& Mohd Suki (2015) and Bengtsson, \& Wincent (2011). 
However, an analysis of the effect of employee branding and advertising on brand equity is still moderate. Therefore, in this study, we investigate the relationship of corporate positioning in the context of employee branding and advertising on brand equity.

\section{LITERATURE REVIEW}

\section{Corporate Positioning}

Positioning refers to how customers think about proposed and/or present brands in a market (Perreault, Perreault, \& McCarthy, 2001). Through a brand's positioning, a company tries to build a sustainable competitive advantage of product attributes - tangible or intangible - in the consumer mind. This advantage is designed to appeal to one or more segments in the product category. Developing a successful positioning strategy is not easy Schnedler (1996) stated that positioning is one of a company's burdensome decisions.

\section{Brand Equity}

Aaker (2012) noticed that brand equity is a set of assets and liabilities linked to a brand name and symbol that adds to or subtracts from the value provided by a product or service to firm and firm's customers. Brand equity is a value and strength of the brand that decides it's worth. It can also be defined as the differential impact of brand knowledge in consumer's response to brand marketing. Brand equity exists as a function of consumer choice in the market place. The concept of brand equity comes into existence when a consumer chooses a product or a service. It occurs when the consumers are familiar with the brand and holds some favorable positive, strong, and distinctive brand associations in their memories. Several aspects of the definition deserve elaborations. First, brand equity is an asset. Thus, the management of brand equity involves investment to create and enhance the asset. Each asset creates value in a variety of very different ways. To manage brand equity effectively and to make informed decisions about brand-building activities, it is important to be sensitive to how strong brands create value. Brand equity creates value for the customer as well as the firm. The customers refer to both end- users and those at the infrastructure level. Moreover, assets or liabilities must be linked to the name and symbol of the brand. Therefore, any change of brand name or symbol will affect assets or liabilities, even though some might be shifted to the new name and symbol.

\section{The Relationship between Corporate Positioning and Brand Equity}

Positioning is not what is accomplished to the product, but what is created in the consumer's mind, through various communications. Corporate positioning is a set of associations the consumer has with the brand. These may cover physical attributes, lifestyle, and user image. A corporate positioning in a consumer's mind is a relative concept that refers to a comparative assessment of the consumer of how this brand is similar to or different from the other brands (Sengupta, 2005). The corporate positioning guides the current communication programs and it is distinct from a general brand identity constructed. Some elements of brand identity such as cleanliness may not be actively communicated, and other elements such as a product class association will recede the brand visibility as well as the brand matures. Corporate positioning is a part of the brand identity and value proposition to be actively communicated to a target audience. Corporate positioning involves identifying and determining points of similarity and difference to ascertain the right brand identity and to create a proper brand image. For this reason, corporate positioning is a key to marketing strategy.

A strong corporate positioning directs marketing strategy by explaining the brand details, the uniqueness of the brand and its similarity with the competitive brands, as well as the reasons for buying and using a specific brand. Positioning is an underlying concept for developing and increasing the required knowledge and perceptions of customers. It is the single feature that sets your service apart from your competitors. By shaping consumer preferences, corporate positioning strategies are directly linked to consumer loyalty, consumer-based brand equity and the willingness to purchase a respective brand. Effective corporate 
positioning can be referred to as an extent to which a brand is perceived as favorable, different and credible in consumers' minds. Corporate positioning is a medium through which an organization can portray its customers of what they require and stand for. It forms customer's views and opinions.

In this study, we define corporate positioning in the context of employee branding and advertising. Biedenbach, Bengtsson, \& Wincent (2011) and Sirianni, Bitner, Brown, \& Mandel (2013) proved there is a significant relationship between employee branding and brand equity. Employee behavior is a part of brand positioning that significantly strengthens a corporate's brand equity. Moreover, in terms of advertising, Buil, De Chernatony, \& Martínez (2013), Alhaddad (2015), and Guitart, Gonzalez, \& Stremersch (2018) have signified the relationship of the variable and brand equity. According to the theoretical background, the following hypothesis is proposed and the conceptual background is depicted in Figure 1

Hypothesis (H): Corporate positioning has a positive effect on brand equity

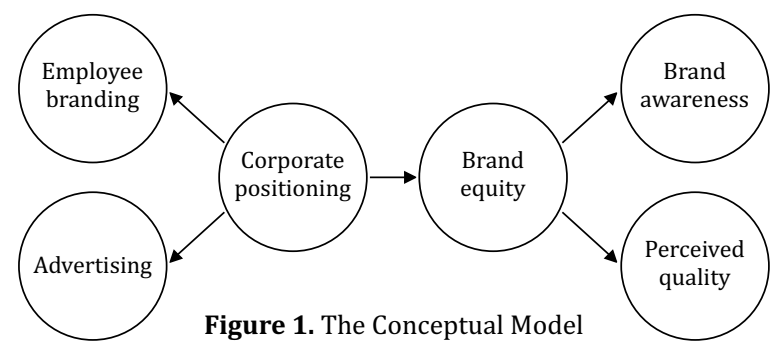

\section{METHODOLOGY}

\section{Sample and instruments}

Data were collected from 200 Gramedia customers. The stores were located in Pondok Indah, Central Park, Mall Metropolitan Bekasi, Mall of Indonesia, and Grand Indonesia by using random sampling. The questionnaires employed five-points Likert scale with five alternative answers, i.e. strongly agree (5), agree (4), disagree/sometimes (3), disagree (2), and strongly disagree (1). The final questionnaires consist of two dimensions on corporate positioning and two dimensions on brand equity construct. The dimensions of corporate positioning are employee branding and advertising, while the dimensions of brand equity are perceived quality and brand awareness. Each dimension accommodates three indicators, except for advertising where it has four indicators. Overall, there are 13 indicators included in the SEM model and analysis.

\section{Data analysis}

This study was carried out by using SEM which was run by the AMOS statistical program. SEM is an extension of the General Linear Model (GLM) that enables a researcher to test a set of regression equations simultaneously. SEM software can test traditional models, but it also permits examination of more complex relationships and models, such as Confirmatory Factor Analysis (CFA) and timeseries analyses. The SEM and traditional statistic methods (e.g., Regression, Anova, Logit) differ in some ways (Gefen, Straub, \& Boudreau, 2000) whereas traditional statistic methods can only test pairwise relationships between observed variables.

\section{RESULTS AND DISCUSSIONS}

\section{Respondent characteristics}

Most of the respondents in this study are male (63\%). Most of them had aged between 21-30 years old (81.5\%), between $31-40$ years old (16.5 $\%$ ) and between 41-50 years old (2\%). In addition, out of 200 respondents, $52.5 \%$ of which are high school and undergraduate students and $47.5 \%$ of which are employees.

\section{Confirmatory Factor Analysis (CFA)}

CFA is used to test whether measures of a construct are consistent with a researcher's understanding of the nature of the respective construct. Four criteria are used as summarized in Table 1. The first criterion is RMSEA (Root Mean Square Error of Approximation). The RMSEA is acceptable or good when the value is less than 0.080 . The second criterion is the GFI (goodness-of-fit index). The GFI is acceptable when the value is greater than 0.900. Although in this study, the value of GFI is less than 0.900, it does not necessarily mean that the model has a poor fit because the 
GFI is scaled between 0 and 1 , where higher values indicate a better model fit. The third criterion is RMR (Root Mean Square Residual). RMR is the square root of the mean squared discrepancies between the implied and observed covariance matrices. It is used to compare the fit of two different models with the same data. The RMR is acceptable when the value is less than 0.050. The last criterion is CMIN/DF (Chi-Square Fit Index divided by Degrees of Freedom). The value of CMIN/DF which ranges between 2 to 1 or 3 to 1 indicated an acceptable fit between the hypothetical model and the sample data (Ghozali, 2016).

\section{Validity and Reliability Test}

A validity test is used to measure the accuracy of the instruments used or questionnaire items. To test the validity of questionnaire items, this study used standardized loading factors with a cut-off value of 0.500 (Ghozali, 2016). The result in Table 2 indicated that all items which belong to all variable are valid. Next, the internal reliability of the items was verified by Composite Reliability (CR) and Average Variance Extracted (AVE) value (Ghozali, 2016). The literature suggested that the value of AVE must be higher than 0.500 and the value of CR must be higher than 0.700. Based on the calculation in Table 2, all of the variables are beyond the cut-off values, thus it is concluded that all the constructs have fulfilled adequate reliability.

\section{Structural Model Results}

The results of the hypothesis testing indicated that corporate positioning has a positive effect on brand equity of Gramedia store customers $(=0.799$; c.r.=9.937; P-value=0.001). Figure 3 depicted the result of the SEM model estimation. The result supports the proposed hypothesis. Moreover, the result gives a support to the studies of Biedenbach, Bengtsson, \& Wincent (2011), Sirianni, Bitner, Brown, \& Mandel (2013), Buil, De Chernatony, \& Martínez (2013), Alhaddad (2015), and Guitart, Gonzalez, \& Stremersch (2018) in terms of the positive effect of employee branding and

Table 1. Result of Goodness of Fit Model Test

\begin{tabular}{|c|c|c|c|c|c|c|c|}
\hline \multirow{2}{*}{ Criteria } & \multirow{2}{*}{ Cut-off Values } & \multicolumn{2}{|c|}{ Exogenous Model } & \multicolumn{2}{c|}{ Endogenous Model } & \multicolumn{2}{c|}{ Full Model } \\
\cline { 3 - 8 } & & Values & Results & Values & Results & Values & Results \\
\hline GFI & $\geq 0.90$ & 0.952 & Good & 0.983 & Good & 0.961 & Good \\
\hline RMSEA & $\leq 0.08$ & 0.029 & Good & 0.062 & Good & 0.000 & Good \\
\hline CMIN/DF & $1 \leq \mathrm{X} \leq 2$ or $1 \leq \mathrm{x} \leq 3$ & 1.212 & Good & 1.757 & Good & 0.949 & Good \\
\hline RMR & $\leq 0.05$ & 0.016 & Good & 0.014 & Good & 0.026 & Good \\
\hline
\end{tabular}

Table 2. Result of Construct Validity and Reliability Test

\begin{tabular}{|c|c|c|c|c|c|c|}
\hline Variables & Dimensions & Indicators & $\lambda$ & AVE & CR & Reliabilities \\
\hline \multirow{7}{*}{$\begin{array}{l}\text { Corporate } \\
\text { Positioning }\end{array}$} & \multirow{4}{*}{ Employee Branding } & Eb3 & 0.917 & \multirow{4}{*}{0.763} & \multirow{4}{*}{0.873} & \multirow{4}{*}{ reliable } \\
\hline & & EB2 & 0.873 & & & \\
\hline & & EB1 & 0.828 & & & \\
\hline & & AD3 & 0.904 & & & \\
\hline & \multirow{3}{*}{ Advertising } & $\mathrm{AD} 2$ & 0.887 & \multirow{3}{*}{0.803} & \multirow{3}{*}{0.928} & \multirow{3}{*}{ reliable } \\
\hline & & $\mathrm{AD} 1$ & 0.903 & & & \\
\hline & & $\mathrm{AD} 4$ & 0.891 & & & \\
\hline \multirow{6}{*}{$\begin{array}{l}\text { Brand } \\
\text { Equity }\end{array}$} & \multirow{3}{*}{ Brand awareness } & BAW3 & 0.906 & \multirow{3}{*}{0.826} & \multirow{3}{*}{0.881} & \multirow{3}{*}{ reliable } \\
\hline & & BAW2 & 0.918 & & & \\
\hline & & BAW1 & 0.903 & & & \\
\hline & \multirow{3}{*}{ Perceived quality } & PQ3 & 0.832 & \multirow{3}{*}{0.716} & \multirow{3}{*}{0.866} & \multirow{3}{*}{ reliable } \\
\hline & & PQ2 & 0.866 & & & \\
\hline & & $\mathrm{Pq} 1$ & 0.841 & & & \\
\hline
\end{tabular}


advertising on brand equity. To improve corporate positioning, Gramedia should be more creative to communicate with customer, especially through advertising, since the advertising has a high score in SEM, means that when Gramedia has a good advertising, it will create a positive impact on corporate's brand image. To be able to create a lasting impression in consumer's mind, Gramedia should do differentiation in doing advertising processes. Some proposed ideas including doing cooperation with universities or schools. Books purchased can be sent directly to the university or school address by nearest Gramedia stores. Further, installing best selling books in Trans Jakarta or Commuter line waiting room, along with scannable barcodes, so that customers are allowed to order directly by scanning barcodes using their smart phones, completing payments and choosing the suitable shipping methods. Lastly, doing a collaboration with television media is also suggested to disseminate the stores location and brands

\section{CONCLUSION}

The result of this study indicated that corporate positioning has a positive effect on brand equity of Gramedia customers. By implementing a good corporate positioning, Gramedia will gain a high brand equity. Moreover, the advertising is the most important factor in corporate positioning, while the brand awareness is the most important factor in brand equity. Some managerial implications are suggested such as doing cooperation with universities and $\mathrm{s}$ chools, installing best selling books in public spaces, and doing a collaboration with television media..

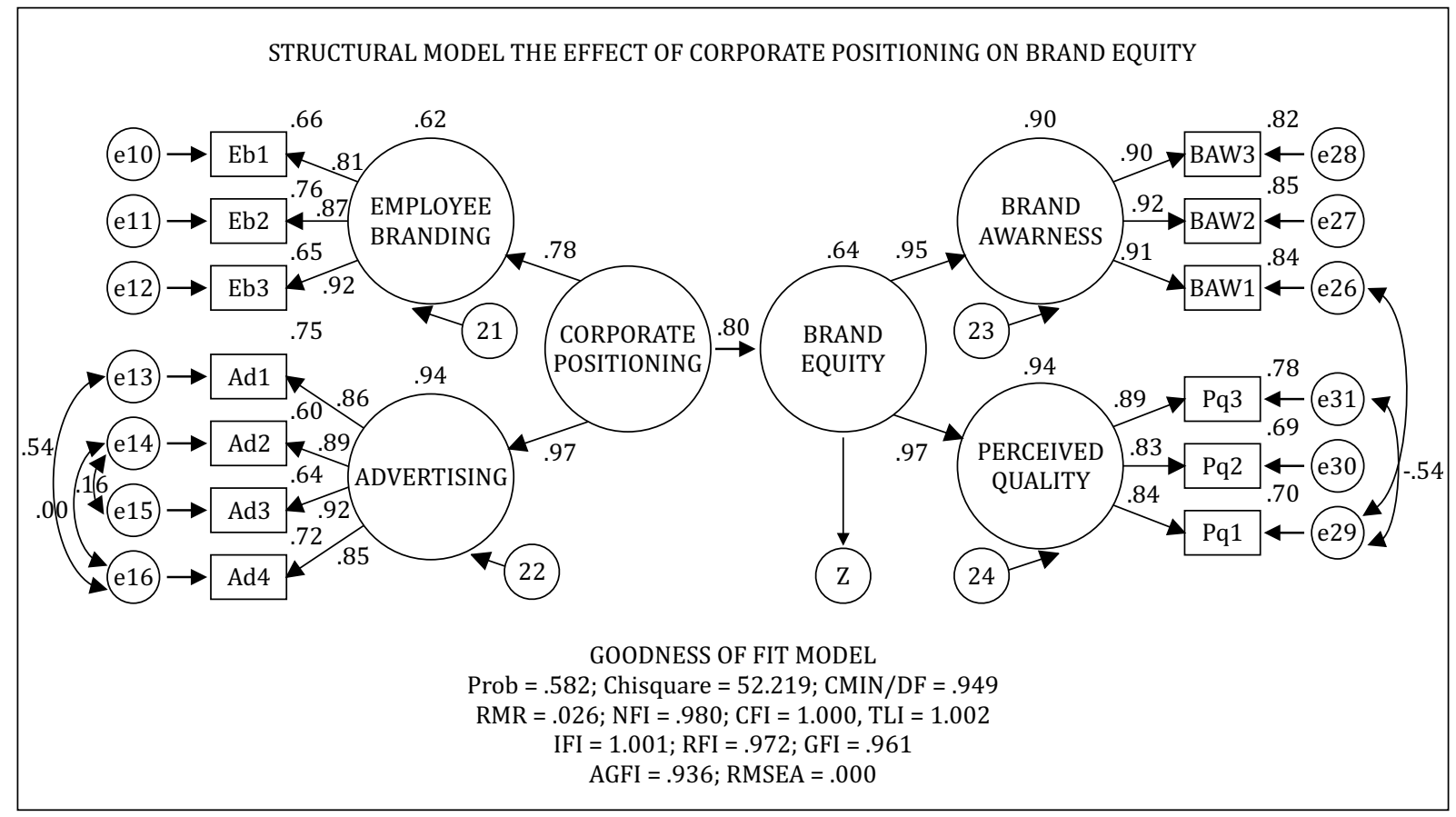

Figure 2. The final result of model estimation

\section{REFERE N C ES}

Aaker, D. A. (2012). Building strong brands. Simon and Schuster.

Alhaddad, A. A. (2015). The effect of advertising awareness on brand equity in social media. International Journal of e-Education, e-Business, e-Management and e-Learning, 5(2), 73.

Ambler, T., \& Styles, C. (1995). Brand equity: towards measures that matter. London Business School. 
Biedenbach, G., Bengtsson, M., \& Wincent, J. (2011). Brand equity in the professional service context: Analyzing the impact of employee role behavior and customer-employee rapport. Industrial Marketing Management, 40(7), 1093-1102.

Buil, I., De Chernatony, L., \& Martínez, E. (2013). Examining the role of advertising and sales promotions in brand equity creation. Journal of Business Research, 66(1), 115-122.

Gefen, D., Straub, D., \& Boudreau, M. C. (2000). Structural equation modeling and regression: Guidelines for research practice. Communications of the association for information systems, 4(1), 7.

Ghozali, I. (2016). Aplikasi Analisis Multivariete dengan Program IBM SPSS 23, Edisi Delapan. Penerbit Universitas Diponogoro. Semarang.

Guitart, I. A., Gonzalez, J., \& Stremersch, S. (2018). Advertising non-premium products as if they were premium: The impact of advertising up on advertising elasticity and brand equity. International Journal of Research in Marketing, 35(3), 471-489.

Iglesias, O., Markovic, S., \& Rialp, J. (2019). How does sensory brand experience influence brand equity? Considering the roles of customer satisfaction, customer affective commitment, and employee empathy. Journal of Business Research, 96, 343-354.

Kao, T. W. D., \& Lin, W. T. (2016). The relationship between perceived e-service quality and brand equity: A simultaneous equations system approach. Computers in Human Behavior, 57, 208-218.

Lassar, W., Mittal, B., \& Sharma, A. (1995). Measuring customer-based brand equity. Journal of consumer marketing, 12(4), 11-19.

Park, C. S., \& Srinivasan, V. (1994). A survey-based method for measuring and understanding brand equity and its extendibility. Journal of marketing research, 31(2), 271-288.

Perreault, J., Perreault, W. D., \& McCarthy, E. J. (2001). Applications in basic marketing: clippings from the popular business press. McGraw-Hill College.

Roberts, P. W., \& Dowling, G. R. (2002). Corporate reputation and sustained superior financial performance. Strategic managementjournal, 23(12), 1077-1093.

Sasmita, J., \& Mohd Suki, N. (2015). Young consumers' insights on brand equity: Effects of brand association, brand loyalty, brand awareness, and brand image. International Journal of Retail \& Distribution Management, 43(3), 276-292.

Sengupta, S. (2005). Brand positioning: Strategies for competitive advantage. Tata McGraw-Hill Education.

Sirianni, N. J., Bitner, M. J., Brown, S. W., \& Mandel, N. (2013). Branded service encounters: Strategically aligning employee behavior with the brand positioning. Journal of Marketing, 77(6), 108-123.

Yoo, B., Donthu, N., \& Lee, S. (2000). An examination of selected marketing mix elements and brand equity. Journal of the academy of marketing science, 28(2), 195-211. 